\title{
A Manual Kinetic Assay in a Fixed Yeast Model for Drug Discovery
}

\author{
Vahe Nahapetyan, Shiela Delos Santos, Kristel Joy Crocker, Dayana Tobar, Dante Nazarian, \\ Hovannes Chirishyan, Gerard Beltran, Rachel Dubin, Leticia Reque, Prabkiran Singh, \\ Brandie Cardona, Graciel Royce Bachinela, Lillyt Sarkisyan, Gregory Zem, \\ Steven Oppenheimer"
}

Department of Biology and Center for Cancer and Developmental Biology, California State University, Northridge, United States

Email address:

steven.oppenheimer@csun.edu (S. Oppenheimer)

*Corresponding author

\section{To cite this article:}

Vahe Nahapetyan, Shiela Delos Santos, Kristel Joy Crocker, Dayana Tobar, Dante Nazarian, Hovannes Chirishyan, Gerard Beltran, Rachel Dubin, Leticia Reque, Prabkiran Singh, Brandie Cardona, Graciel Royce Bachinela, Lillyt Sarkisyan, Gregory Zem, Steven Oppenheimer. A Manual Kinetic Assay in a Fixed Yeast Model for Drug Discovery. American Journal of Applied Scientific Research.

Vol. 5, No. 1, 2019, pp. 28-34. doi: 10.11648/j.ajasr.20190501.15

Received: May 12, 2019; Accepted: June 10, 2019; Published: June 24, 2019

\begin{abstract}
Manual cell counting assays are often considered as a gold standard in some applications because of direct observation of results. Here a manual kinetic cell counting method is used to evaluate the efficacy of reagents to unclump cells in a fixed yeast (Saccharomyces cerevisae) model. Clumped cells are more dangerous than single cells in many human venues such as cancer spread, thrombocytic blockages and biofilm infectivity. In this study percentage of single cells are analyzed over time in the presence or absence of specific reagents and the number of cell clumps and cells per clump are also assessed. The results show that when the percentage of single cells increases, the number of clumps and cells per clump decrease, helping to validate the assay. These findings suggest that this assay can be a gold standard for evaluating the effects of specific reagents on cell unclumping in a model system that can be used in drug discovery investigations. This study is part of a program that won a U.S. Presidential Award for science mentoring presented by President Obama at the White House. The experiments are easily accomplished by undergraduate students and can be done by research classes without background in complex science methodology.
\end{abstract}

Keywords: Cell Unclumping Kinetic Assay, Fixed Yeast Model, Drug Discovery

\section{Introduction}

This laboratory has developed and uses a manual (nonautomated) cell counting assay for examining the kinetics of cell interactions in a yeast model. Results have been reported previously only in abstract and poster form [1,2,3]. This program has helped win a U.S. Presidential Award for Science Mentoring presented by President Obama at the White House [4-8].

Manual cell counting is considered a gold standard in some applications because of direct observation of results [9]. This laboratory uses this assay to evaluate the efficacy of reagents in unclumping cells. Reagents that unclump cells could be useful in unclumping cancer cells, unclumping thrombocytic blockages and reducing biofilms. Single cells are often less dangerous than cell clumps in each of these venues. Here, the assay is tested by not only measuring single cell populations over time but also measuring clump number and number of cells per clump.

\section{Experimental Procedure}

In over 400 trials by 14 investigators, sodium citrate dihydrate or magnesium sulfate was added at 0 (control), 1, 2 and $3 \mathrm{mg}$ (as represented by toothpick tips, as explained later), per ml deionized water on glass microscope slides for their effects on Prefer (Anatech Ltd, Battle Creek, MI) fixed yeast, Saccharomyces cerevisiae $(0.1 \mathrm{ml})$. Percent single 
cells was measured before adding reagent (00 time), right after adding reagent ( 0 time) and at $20 \mathrm{~min}, 40 \mathrm{~min}$ and 60 min after adding reagent with gentle stirring every $20 \mathrm{~min}$ (for 10 seconds) with birchwood flat toothpicks (Diamond, Daleville, IN). All experiments were done at room temperature. In addition at the $60 \mathrm{~min}$ time, number of clumps and number of cells per clump were assessed by direct observation using light microscopes. All data were plotted with standard deviations and two-tailed t-tests were conducted on experimental vs control results.

\section{Results and Discussion}

It was generally observed that when there was no significant change in percentage of single cells in experimentals and controls (no reagent) $(p>0.05)$, there was no significant change in number of clumps and number of cells per clump ( $p>0.05)$. This is shown in Figure $1 \mathrm{a}, \mathrm{b}, \mathrm{c}$ with magnesium sulfate. When there was a significant increase in percent single cells (suggesting that the reagent caused cell unclumping), there was a reduction in clump number and number of cells per clump. Examples of this finding are shown in the Figures 2, 3, 4. For 30 trials for 1 tip (mg) sodium citrate dihydrate per $\mathrm{ml}$ deionized water, there was a $20 \%$ increase in percent single cells by $60 \mathrm{~min}$ vs controls with a $\mathrm{p}$ value $<0.01$ comparing percent single cells in experimentals and controls. (Figure 2a). The bar graphs show that the number of clumps at 60 min was reduced by 33 percent in experimentals vs controls and the number of cells per clump was reduced by 30 percent. $\mathrm{P}$ values in both cases of clump measurements were $<0.01$ comparing experimentals and controls (Figures $2 \mathrm{~b}, \mathrm{c}$ ).
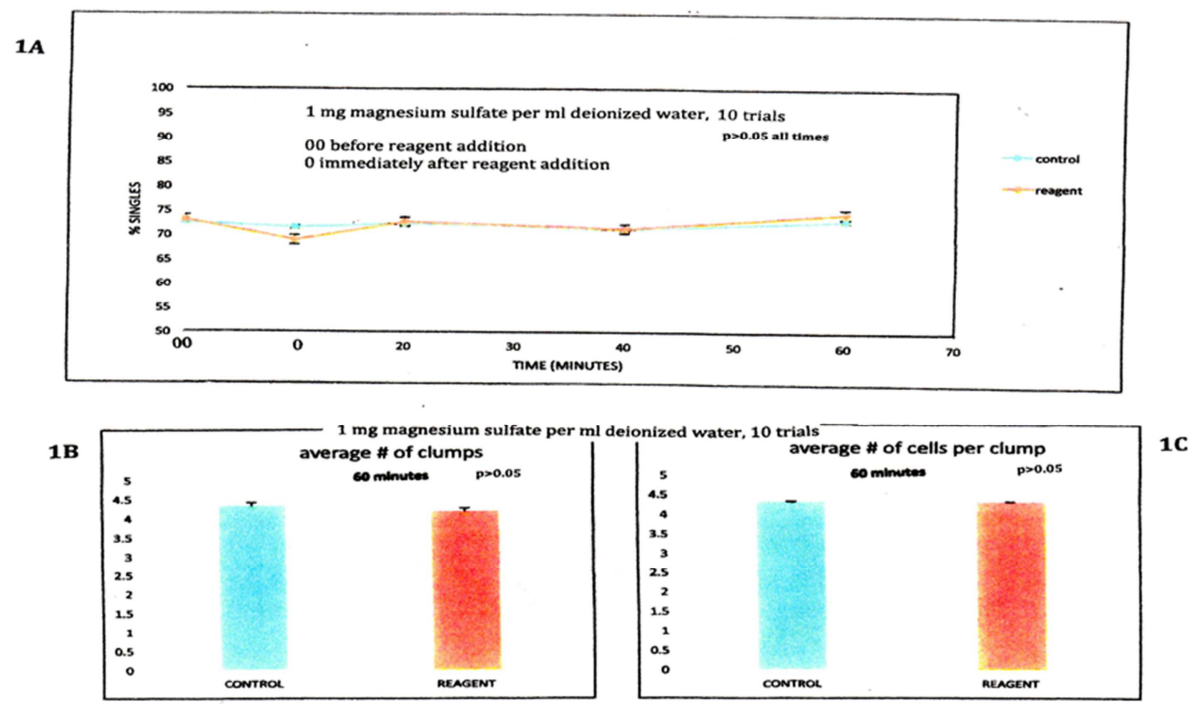

Figure 1. Fixed yeast manual assay. No difference in controls and experimentals (magnesium sulfate $1 \mathrm{mg}$ per ml deionized water) A. No difference in percent singles fixed yeast, $B$. No difference in average number of clumps fixed yeast, $C$. No difference in average number of cells per clump fixed yeast.

$\mathbf{2 A}$

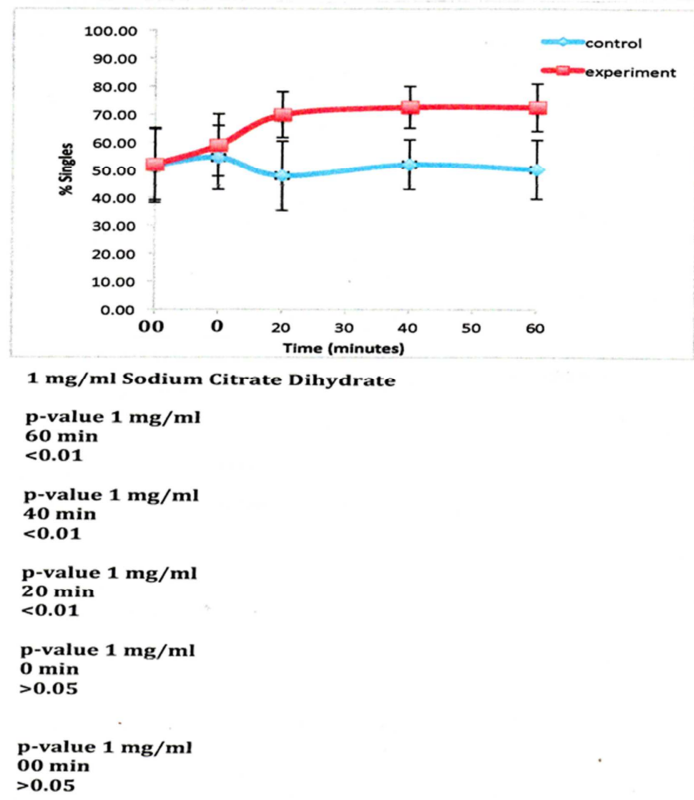




\section{B}

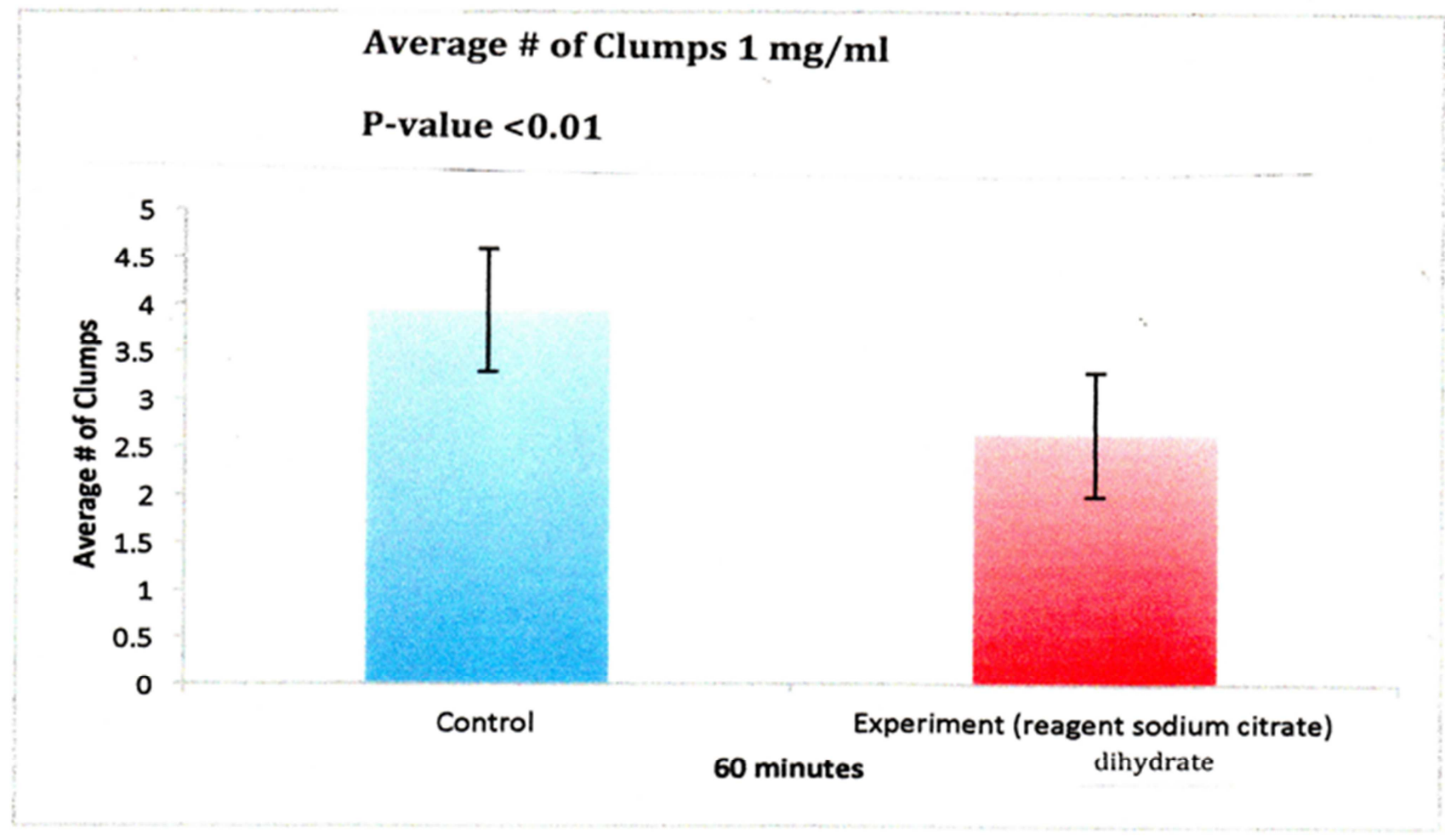

\section{C}

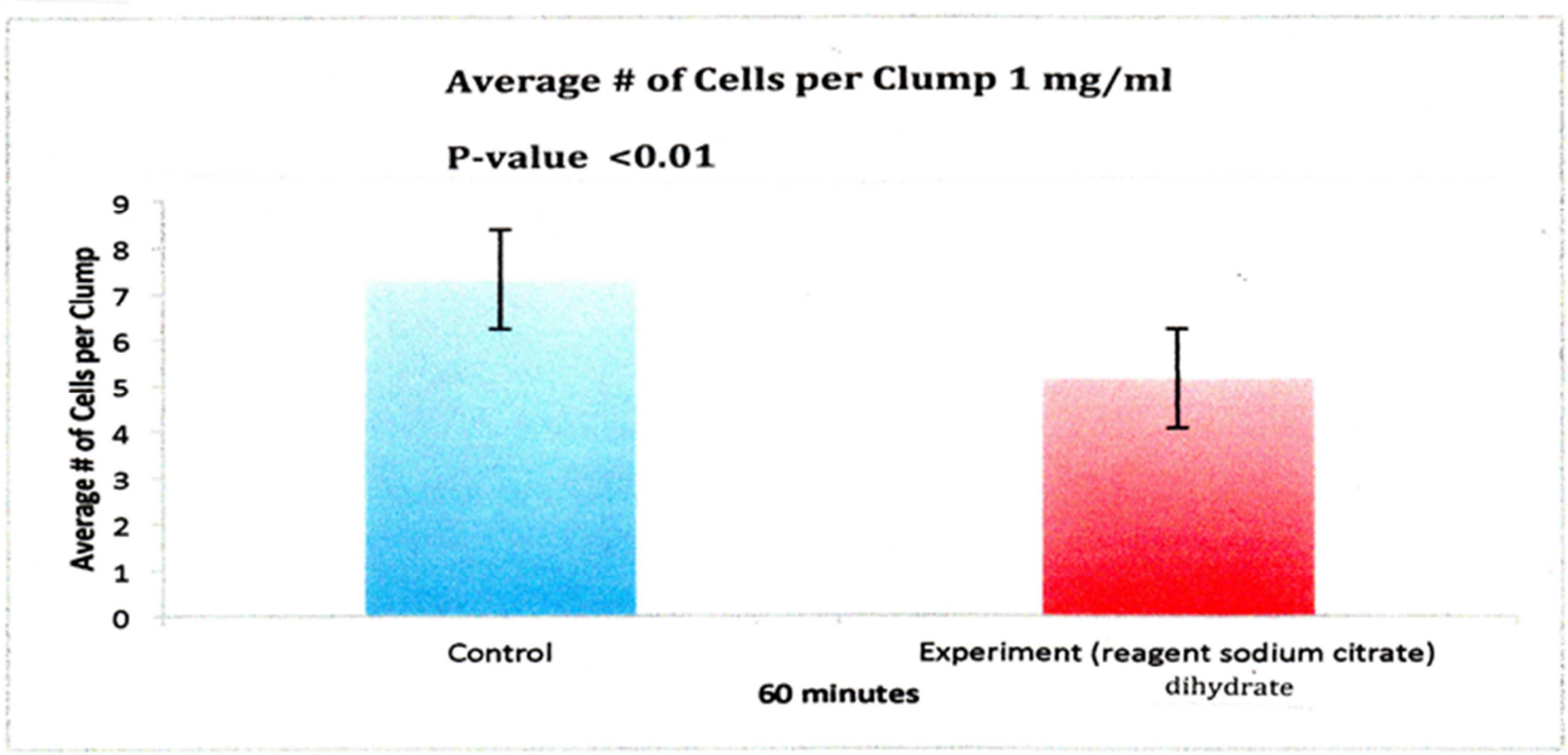

Figure 2. Fixed yeast manual assay. $1 \mathrm{mg}$ sodium citrate dihydrate per $\mathrm{ml}$ deionized water. A. percent singles over 60 min time course. B. average number of clumps. C. average number of cells per clump.

For 2 tips (mg) sodium citrate dihydrate per $\mathrm{ml}$ deionized water there was a 27 percent increase in single cells by 60 min vs controls with $\mathrm{p}$ values $<0.01$ comparing percent single cells in experimentals and controls (Figure $3 \mathrm{a}$ ). The bar graphs show that the number of clumps at 60 min was reduced by 33 percent in experimentals vs controls and the number of cells per clump was reduced by 39 percent. $P$ values in both cases of clump measurements were $<0.01$ comparing experimentals and controls (Figure $3 \mathrm{~b}, \mathrm{c}$ ). 
$3 \mathbf{A}$

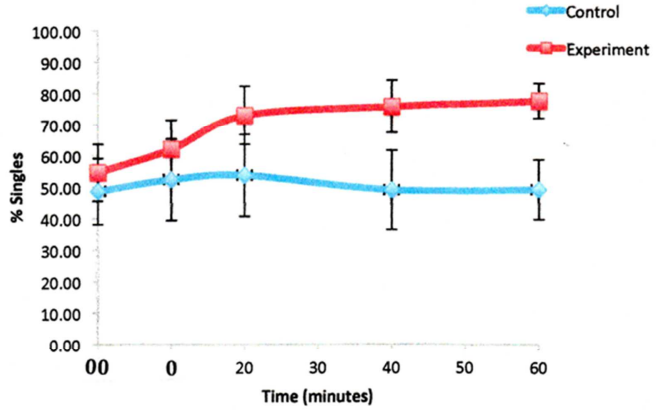

$2 \mathrm{mg} / \mathrm{ml}$ Sodium Citrate Dihydrate

p-value $2 \mathrm{mg} / \mathrm{ml}$

$60 \mathrm{~min}$

$<0.01$

p-value $2 \mathrm{mg} / \mathrm{ml}$

$40 \mathrm{~min}$
$<0.01$

p-value $2 \mathrm{mg} / \mathrm{ml}$

20 min

$<0.01$

p-value $2 \mathrm{mg} / \mathrm{ml}$

0 min
$<0.05$

p-value $2 \mathrm{mg} / \mathrm{ml}$

$00 \mathrm{~min}$

$<0.05$

3B

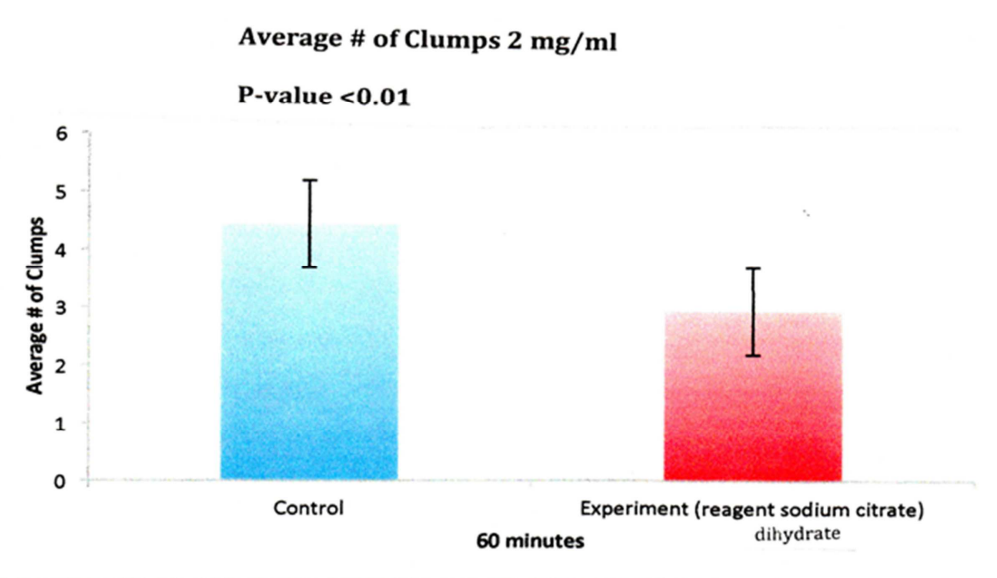

3C

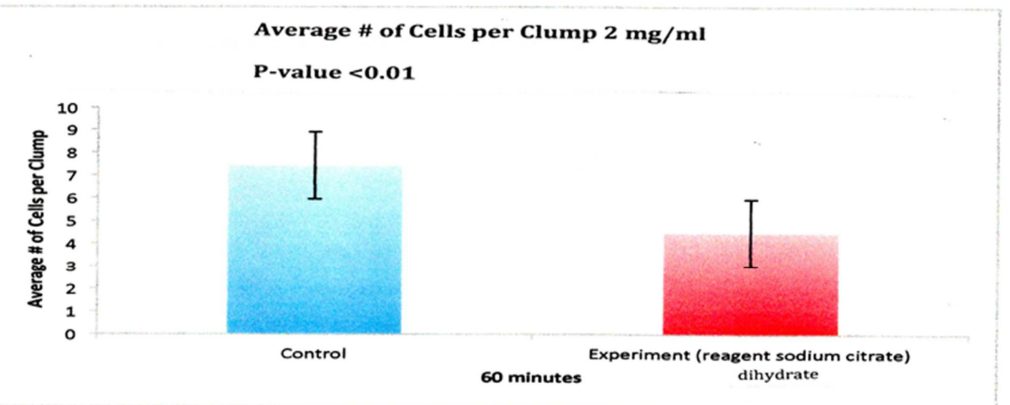

Figure 3. Fixed yeast manual assay. $2 \mathrm{mg}$ sodium citrate dihydrate per $\mathrm{ml}$ deionized water. A. percent singles over $60 \mathrm{~min}$ time course. B. average number of clumps. C. average number of cells per clump. 
For 3 tips (mg) sodium citrate dihydrate per $\mathrm{ml}$ deionized water, there was a 35 percent increase in single cells by 60 min vs controls with a $\mathrm{p}$ value of $<0.01$ comparing percent single cells in experimentals and controls (Figure 4a). The bar graphs show that the number of clumps at 60 min was reduced by 56 percent and the number of cells per clump was reduced by 39 percent. $P$ values in both cases of clump measurements were $<0.01$ comparing experimentals and controls (Figure 4b, c).

$4 A$

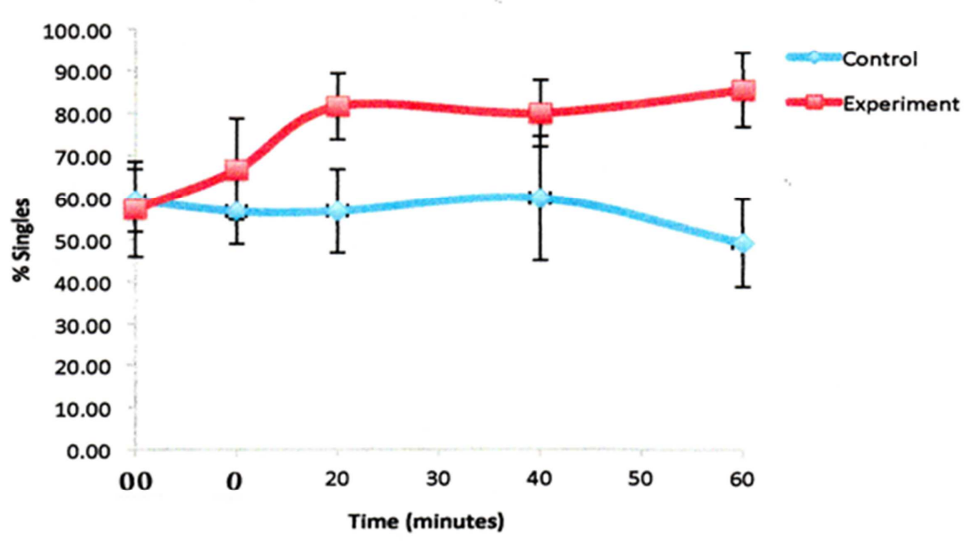

$3 \mathrm{mg} / \mathrm{ml}$ Sodium Citrate Dihydrate

p-value $3 \mathrm{mg} / \mathrm{ml}$

$60 \mathrm{~min}$

$<0.01$

p-value $3 \mathrm{mg} / \mathrm{ml}$

40 min

$<0.01$

p-value $3 \mathrm{mg} / \mathrm{ml}$

20 min

$<0.01$

p-value $3 \mathrm{mg} / \mathrm{ml}$

0 min

$<0.05$

p-value $3 \mathrm{mg} / \mathrm{ml}$

$00 \mathrm{~min}$

$>0.05$

4B

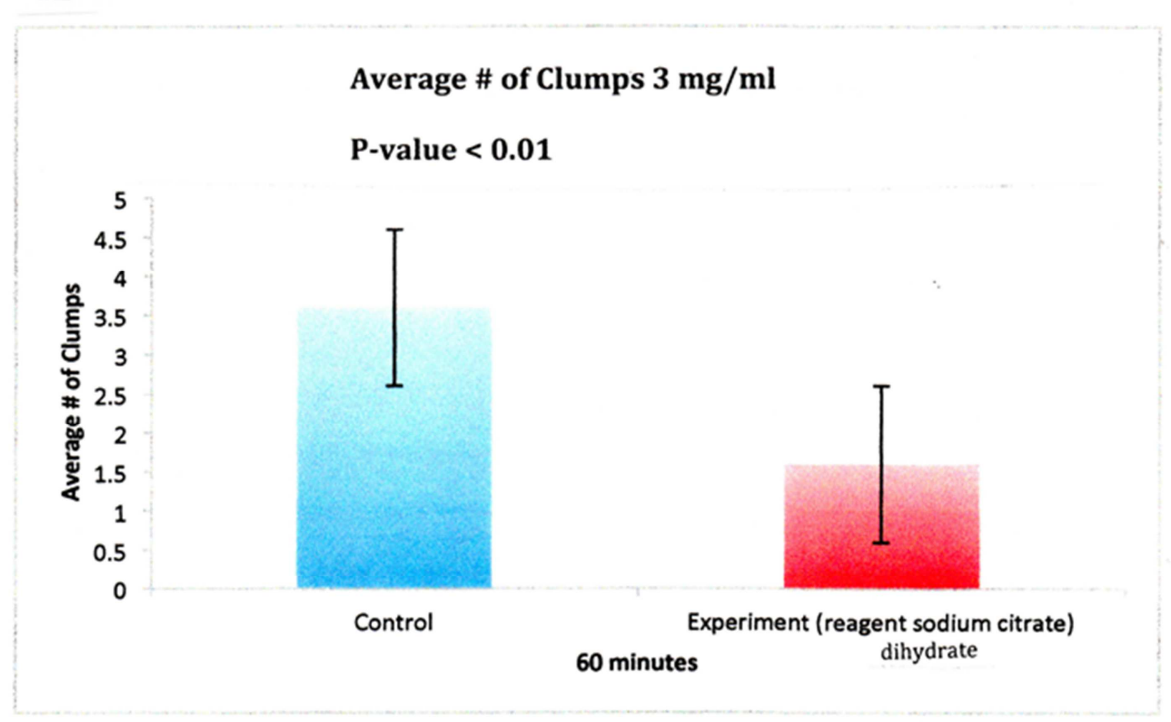




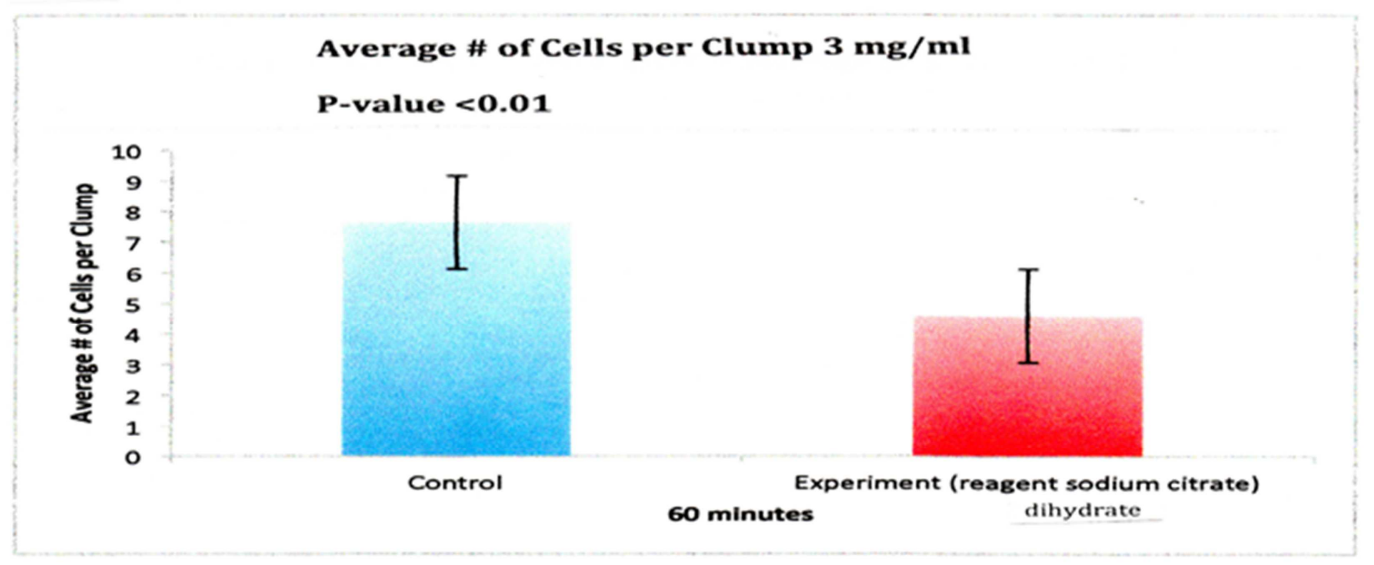

Figure 4. Fixed yeast manual assay. $3 \mathrm{mg}$ sodium citrate dihydrate per $\mathrm{ml}$ deionized water. A. percent singles over $60 \mathrm{~min}$ time course. B. average number of clumps. C. average number of cells per clump.

In this sample of 30 trials there was generally a concentration dependent effect of sodium citrate dihydrate on unclumping of yeast cell clumps. Figures 2, 3 and 4 show $\mathrm{p}$ values of $<0.01$ for all times except for the initial times before the curves begin to separate.

This assay is used to survey cell populations in kinetic studies. Manual cell counting protocols, like this one, are generally used to count cells on a slide. We know of no other assay in which cells are stirred on a slide over time and observed at given time intervals to obtain kinetic data. In this assay slides with cells and cell clumps, with and without specific reagents, in droplets of deionized water, are observed at given time intervals after stirring. Drying is prevented by inverting plastic culture dishes over the slides on the stages of inverted light microscopes. Direct observation indicates that there is no sticking of the cells or cell clumps to the glass slides or toothpicks, maybe because we always used fixed cells in these experiments. Previous work indicated that the surface properties of fixed yeast cells are similar to the surface properties of live cells [10].

We use Prefer fixative, shown to be as effective as formaldehyde, and safer than formaldehyde, in preserving authentic surface properties [10].

The drawbacks of this assay include investigator variability, just like when visually scoring immunohistochemical results, slow procedures compared to automated assays and inability to assess huge quantities of cell samples. These drawbacks are similar for all manual cell counting methods that involve microscopic examinations. Despite these drawbacks, manual cell counting methods continue to be procedures of choice for many applications.

Tips vs mg: The approximate equivalence of toothpick tips and $\mathrm{mg}$ was independently checked. For example, 1 tip, 2 tips and 3 tips on flat toothpicks have been checked and represent approximately 1,2 and $3 \mathrm{mg}$ of reagent respectively.

Such estimates speed up the assay and promising results can be later verified by precise measurements. Of major importance in these studies is $1 \mathrm{X}, 2 \mathrm{X}$ and $3 \mathrm{X}$ the quantity of reagent is what determines how a reagent acts on cells. Whether it's $1.1 \mathrm{mg}, 2.2 \mathrm{mg}$ or $3.3 \mathrm{mg}$ instead of $1.0 \mathrm{mg}, 2.0 \mathrm{mg}$ or $3.0 \mathrm{mg}$ makes no difference in action of a reagent on cells as verified by observations.

The goal of this study was to measure clump number and number of cells per clump in addition to the measurement of percent single cells. The results help validate this assay in showing that clump number and cells per clump decrease as percentage of single cells increases. It doesn't seem to matter if the initial cell samples contain variable numbers of single cells and cell clumps, as each trial examines cell and clump population changes over time.

While automated cell counting methods can be used to analyze huge numbers of samples, manual methods such as the one presented here, especially with the clump counting validation, can be considered a gold standard because of direct observation of all results [9].

Cell clumps play major roles in thrombocytic events and sodium citrate, independently shown here, with single cell as well as clump analysis, in a yeast model, separates clumps [11].

Aggregates of circulating tumor cells seed distant colonies with greater efficiencies than individual cells. Cell clusters may have 50 times greater metastatic potential than individual cells $[12,13]$.

Biofilms are involved in infectivity and here again reagents that can cause biofilm disassembly are of interest clinically $[14,15]$. This research program has been previously published in refereed abstract form and nationally presented in poster format [1-3]. This is the first presentation as a full length paper. This research program helped win a U.S. Presidential Award for science mentoring (PAESMEM) presented by President Obama at the White House [4-8]. It is useful in the design of research studies $[14,9]$ and in student training venues [4-8],

\section{Conclusions}

The validated direct observation kinetic assay presented 
here can be considered as a gold standard for precise measurement of reagent effects on cell unclumping. It is a model for identifying reagents that could be useful in human applications in cancer spread, thrombocytosis and infectivity.

\section{Acknowledgements}

This work was instrumental in the receipt of a U.S. Presidential Award for science mentoring by Steven Oppenheimer (NSF Proposal 0731633). Various accounts in the CSUN Foundation and Corporation (E1266) and support by the CSUN Department of Biology and Center for Cancer and Developmental Biology supported these studies. Most of the co-authors are senior level students mentored by Steve Oppenheimer. We thank Carolyn Oppenheimer for outstanding assistance with the manuscript and figures.

\section{References}

[1] G. Zem, B. Cooperman, F. Bahri, A. Mahjoubi, N. Warner, L. Malekian, R. Mirebrahimian, M. Pistalu, M. Patel, E. Choi, T. Baronian, O. Gilani, A. Cardenas, A. Hambarsoomian, D. Gomez, F. Gallgos, J. Holmes, V. Vahdati, L. Jorshari, P. Grigorian, K. Ohanessian, E. Baum, G. Majarian, K. Aldzhyan, H. Manasyan, N. Allatakakhsh, S. Oppenheimer Reliability of yeast unclumping assay, a model for testing potentially clinically useful reagents FASEB J, 29 (2015), abstract 925.3.

[2] G. Zem, A. Chimayan, V. Aleksanyan, J. Gordon, F. Gomez, A. Seyedroubari, J. Chang, T. Botello, N. Tan, D. Arefin, D. Tobar, A. Khachekian, L. Gama, E. Durodola, J. Batty, C. Plascencia, L. Barillas, A. Roverud, S. Kreuz, L. Sarkisyan, F. Lee, J. Munoz, L. Reque, V. Abed, L. Kinog, S. B. Oppenheimer A kinetic assay for non-automated drug screening FASEB J, 32 (2018), abstract 113.

[3] G. Zem, V. Nahapetyan, K. Crocker, D. Tobar, S. Delos Santos, D. Nazarian, J. Hovannes, G. Beltran, R. Dubin, L. Reque, P. Singh, L. sarkisyan, B. Cardona, G. Bachinela, S. B. Oppenheimer Validation of a manual cell counting assay for assessing the kinetics of cell unclumping reagents in drug discovery FASEB J, 33 (2019), abstract 19.

[4] National Science Foundation Excellence Awards in Science and Engineering Program: Presidential Awards for Excellence in Science, Mathematics and Engineering Mentoring (EASE: PAESMEM). Solicitation 16-534. 2019.
[5] OSTP and NSF to honor 140 individuals and organizations with highest US award for teachers and mentors. News Release 18-043, June 25, 2018.

[6] Presidential Awards for Excellence in Science, Mathematics and Engineering Mentoring, NSF Home Page, 2019.

[7] NSF Proposal 07316333, March 6, 2007, Individual-Steven Oppenheimer Mentor, Researcher, Teacher.

[8] Herstein, O. Steven Oppenheimer CSUN Magazine, no. 67 (2016), p. 20.

[9] P. C. Zeidler-Erdely, J. M. Antonini, T. G. Meighan, S-H. Young, T. J. Eve, M. A. Hammer, A. Erdely Comparison of cell counting methods in rodent pulmonary toxicity studies: automated and manual protocols and considerations for experimental design Inhal Toxicol, 28 (2016), pp. 410-420.

[10] V. M. Navarro, S. L. Walker, O. Badali, L. L. Ngo, S. Weerasinghe, M. Barajas, G. Zem, S. B. Oppenheimer Analysis of surface properties of fixed and live cells using derivatized agarose beads Acta Histochem, 104 (2002), pp. 99-106.

[11] K. Germanovich, E. Alessandra Femiaq, C. Y. Cheng, N. Dovlatova, M. Cattaneo Effects of $\mathrm{pH}$ and concentration of sodium citrate anticoagulant on platelet aggregation measured by light transmission aggregometry induced by adenosine diphosphate Platelets, 29 (2018), pp. 21-26.

[12] N. Aceto, A. Bardia, D. T. Miyamoto, M. C. Donandson, B. S. Wittner, J. A. Spencer, M. Yu, A. Pely, A. Engstrom, H. Zhu, B. W. Brannigan, R. Kapur, S. L. Stott, T. Shioda, S. Ramaswamy, D. T. Ting, C. P. Lin, M. Toner, D. A. Haber, S. Maheswaran Circulating tumor cell clusters are oligoclonal precursors of breast cancer metastasis Cell, 28 (2014), pp1110-1122.

[13] S. H. Au, B. D. Storey, J. C. Moore, Q. Tang, Y-L. Chen, S. Javaid, A. F. Sarioglu, R. Sullivan, M. W. Madden, R. O'Keefe, D. A. Haber, S. Maheswaran, D. M. Langenau, S. L. Stott, M. Toner Clusters of circulating tumor cells traverse capillary-sized vessels Proc Natl Acad Sci US, 113 (2016), pp. 4947-4952.

[14] D. Cadena-Herrera, J. E. Esparza-De Lara, N. D. RamirezIbanez, C. A. Lopez-Marales, N. O. Perez, L. F. Flores-Ortiz, E. Medina-Rivero Validation of three viable cell counting methods: manual, semi-automated, and automated Biotechnology Rep, 7 (2015), pp. 9-16.

[15] Kolodkin-Gal, D. Romero, S. Cao, J. Clardy, R. Kolter, R. Losick D-amino acids trigger biofilm disassembly Science 30, (2010), pp. 627-629. 